\title{
STATUS OF SEMI-CAPTIVE MANATEES IN JAMAICA
}

\author{
Antonio A. Mignucci-Giannoni ${ }^{1,2}{ }^{\bullet}$, Ruby A. Montoya-Ospina ${ }^{2}$, and Mario Velasco-Escudero ${ }^{2}$
}

\begin{abstract}
The West Indian manatee (Trichechus manatus) is one of the most endangered species in Jamaica. Four manatees were impounded at the Alligator Hole River on the south coast of the island since 1981. Their semi-captive status was unclear and the present study reports on the documentation of their gender and survival possibilities. The river was surveyed between 18-25 June 1991 by canoeing and snorkeling, interviews were conducted and photographs and documents were examined to ascertain their status, confirm their gender determination and to assess the circumstances of their capture. A total of 10 sightings were recorded, representing three different animals, all females. They were extremely evasive of humans, as they had been mistreated for long periods of time. Two of the animals appeared healthy, but one was observed with a severe cut in its caudal peduncle, produced by a rope and net. Given Jamaica's low manatee population numbers, and the observed degradation of the river, no justification exists to hold three reproducing female manatees apart from the rest of the Jamaican manatee gene pool. It is recommended that the manatees be captured and released at sea, after fitting them with satellite radio-transmitters, which will allow monitoring their re-adaptation to the wild.

Resumen - El manatí de las Indias Occidentales (Trichechus manatus) es una de las especie en mayor peligro de extinción en Jamaica. Cuatro manatíes fueron encerrados en el rio Alligator Hole en la costa sur de la isla desde 1981. Su estatus de semi-cautiverio no estaba claro y nuestro estudio incluye la determinación del sexo de los animales y sus posibilidades de sobrevivencia. El río fue examinado entre el 18 y el 25 junio de 1991 utilizando canoas y a través de "snorkeling", se llevaron a cabo entrevistas y se examinaron fotografías y documentos para analizar su estatus, para confirmar la determinación del sexo y evaluar las circunstancias de su captura. Un total de 10 avistamientos fueron registrados distinguiendo tres animales diferentes, todos hembras. Los animales se mostraron extremadamente evasivos de los humanos, ya que fueron maltratados por largos períodos de tiempo. Dos de los animales aparentan estar saludables, pero uno de ellos fue observado con una herida severa en su pedúnculo, producto de una soga y malla. Debido al bajo número de los individuos de la población de manatíes en Jamaica y la degradación del río, no existe justificación para mantener tres manatíes hembras en madurez reproductiva, aislados del resto del acervo genético de la especie en Jamaica. Se recomienda que los manatíes sean capturados y liberados en el mar después de colocarles radio-transmisores de satélite los cuales permitirán evaluar su re-adaptación al medio ambiente.
\end{abstract}

Keywords: Caribbean, Jamaica, Trichechus manatus, West Indian manatee, semi-captivity.

\section{Introduction}

West Indian manatees (Trichechus manatus) are the most endangered mammal in Jamaica. Little is known about the manatee in this Caribbean island, with initial records found in Goose and Hill (1851), Neish (1896), Lewis (1949) and Woodley (1968). Powell (1978) documented the unusual carnivory of manatees in Jamaica and flew an aerial survey in 1976, only sighting one manatee (Lefebvre et al., 1989). Aerial surveys conducted between 1981 and 1982 (Fairbairn and Haynes, 1982) sighted as many as 13 manatees, and revealed that they were not evenly distributed throughout the island, but inhabited more often than not the south coast. Aerial surveys during 1991 observed only two manatees (Strong et al., 1991), but in April 1993, biologist Thomas Carr (Caribbean Conservation Corporation) observed eight animals in two different surveys (Marsh and Lefebvre, 1994), including three semi-captive manatees in Alligator Hole River. Another two-day aerial survey in 1998 (Lefebvre et al., 2001) documented 11 animals. Manatees are less abundant in Jamaica than in Puerto Rico, as evidenced by similar flight surveys conducted in both islands (Hurst, 1987; Lefebvre et al., 2001). While NRCA (1993) suggested that less than 100 animals remain today in Jamaica, aerial surveys by qualified and experienced observers suggest that the total manatee population is probably not higher than 14 to 30 animals.

Recognizing the highly endangered status of the Jamaican manatee, around 1980 the Natural Resources Conservation Authority (NRCA) initiated an Organization of American States-funded project to manage the remaining population of manatees in Jamaica, and assess the possibilities of holding a small captive population for display, education and breeding. This project, named "Operation Sea Cow", received funding for four years, and resulted in the introduction of four manatees into the semi-captive environment of the Alligator Hole River in the parish of Clarendon (south central coast) and a study detailing the carrying capacity of the river (Hurst, 1987).

By 1984, funding for Operation Sea Cow ceased, and it was not until 1987 that a new project for establishing a management plan for the West Indian manatee was drafted with the support of the United Nations Environmental Program. This project had an overall island focus as well as a specific localized focus on the animals held at the Alligator Hole River. The project intended to: (1) implement an extensive public education campaign, (2) determine the population size and distribution of manatees in Jamaica, (3) determine the carrying capacity of the Alligator Hole River in regards

\footnotetext{
${ }^{1}$ Universidad Metropolitana, Department of Science and Technology, Caribbean Marine Mammal Laboratory. PO Box 361715, San Juan, 00936-1715, Puerto Rico. ${ }^{2}$ Red Caribeña de Varamientos. Caribbean Stranding Network, PO Box 361715, San Juan, 00936-1715, Puerto Rico.

· Corresponding author: mignucci@caribe.net.
} 
to the manatees held there, and (4) determine the status and gender of the animals impounded in the river (Strong et al., 1991). We report on the last objective of the Project for the establishment of a management plan for the West Indian manatee in Jamaica.

\section{Material and Methods}

The research to assess gender and status was conducted at the Alligator Hole River, a $1.9-\mathrm{km}$ long river in the parish of Clarendon, on the south-central coast of Jamaica $\left(17^{\circ} 50.1^{\prime} \mathrm{N}, 7^{\circ} 25.2^{\prime} \mathrm{W}\right.$, Figure 1), between 18 and 25 June 1991. The river averaged in depth $2.6 \mathrm{~m}$ in the upper portion of the river and $3.3 \mathrm{~m}$ in the lower portion, and had a maximum width of $17.8 \mathrm{~m}$. The average water temperature in the river was $24.4^{\circ} \mathrm{C}$. The river was severely undercut on both sides of its middle and lower portions due to the invasive growth nature of the surface vegetation and its side banks. The main species of macrophytes present in the river were, in order of magnitude, common reed (Phragmites australis), common hornwort (Ceratophylum demersum), and long-leaf pondweed (Potamogeton nodosus) (Hurst, 1987).

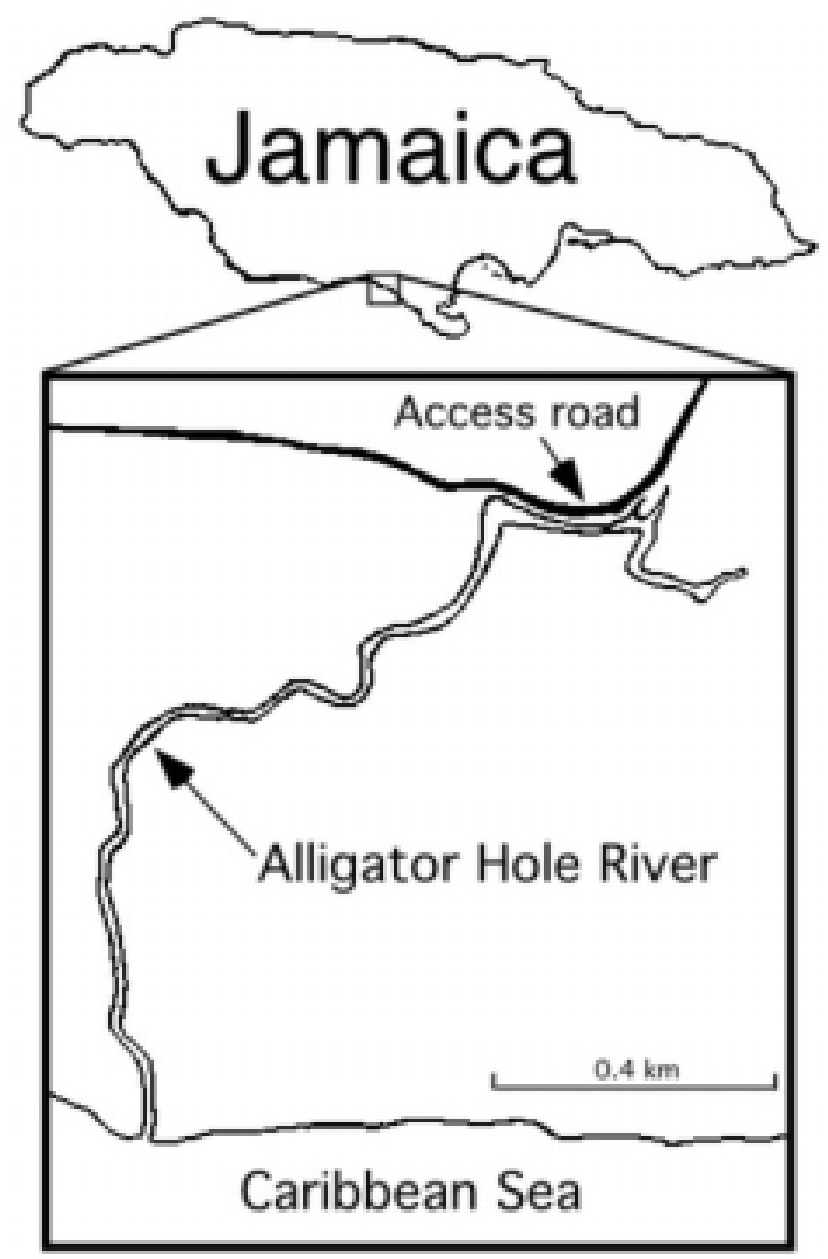

Figure 1. Location of the study area, where manatees are impounded in the Alligator Hole River, Clarendon, Jamaica.
In order to observe the manatees, the river was surveyed by canoeing and snorkeling in its entire length, from its northern end to its sea mouth in June 1991. A total of six canoe trips and eight snorkeling trips were conducted to view the animals underwater, without disturbing them, for individual identification and attempt to determine gender. Listening for and recording of manatee sounds (eating sounds and whistling) using a hydrophone and a Sony VOR recorder (TCM-77V) were conducted both during the day and at night, to confirm the presence of manatees in certain areas of the river. Interviews were conducted and photographs and documents were examined to find evidence for gender assessment of these creatures during their initial capture.

\section{Results}

A total of 10 manatee sightings were recorded during the research period. From these sightings, we were able to identify by markings and body shape three of the animals. Eleven cloud sightings, indicating a fleeing manatee disturbing the bottom's sediments, were also recorded. Combined results from the preliminary investigation, subsequent interviews and sighting records for each manatee follow.

The first manatee impounded in the Alligator Hole River was a young animal about $160 \mathrm{~cm}$ in length, which was captured by a fisherman at Farquhar's Beach in Long Bay between 24 and 26 February 1981 (Figure 2). The animal was confiscated by NRCA (although a payment of J\$550 was made to the fisherman in compensation for the capture) and taken to the Hope Zoo for safe keeping, until a fence in the Alligator Hole River could be constructed to prevent its escape to sea. The animal was kept for 63 days and was promptly released at the river since during its stay at the zoo it did not feed.

The animal at the river was tethered to shore by a $15 \mathrm{~m}$ cotton rope attached to another rope inside a bicycle rubber tube around its caudal peduncle (Figure 3 ). The slow construction of the iron fence at the mouth of the river kept NRCA from releasing the animal for five months. On about 20 September 1981, the swivel attached to the mooring holding the manatee broke and the animal escaped to sea with a piece of rope still tied to its peduncle, as observed by a local fisherman. The animal was recaptured at sea with a net by local fishermen and returned to the river by NRCA staff. The animal broke loose again but was held impounded by fence at the mouth of the river. Hurst (1987) nicknamed this manatee "Dorothy", reporting that it was a female.

We sighted this animal on two occasions on 22 and 24 June 1991. We identified the animal by being a big and stout animal, with some slight mottled coloration on the back (not silver). An underwater photograph of this manatee taken in 1981 and showing it tied to shore revealed partially its ventral peduncle area, which 


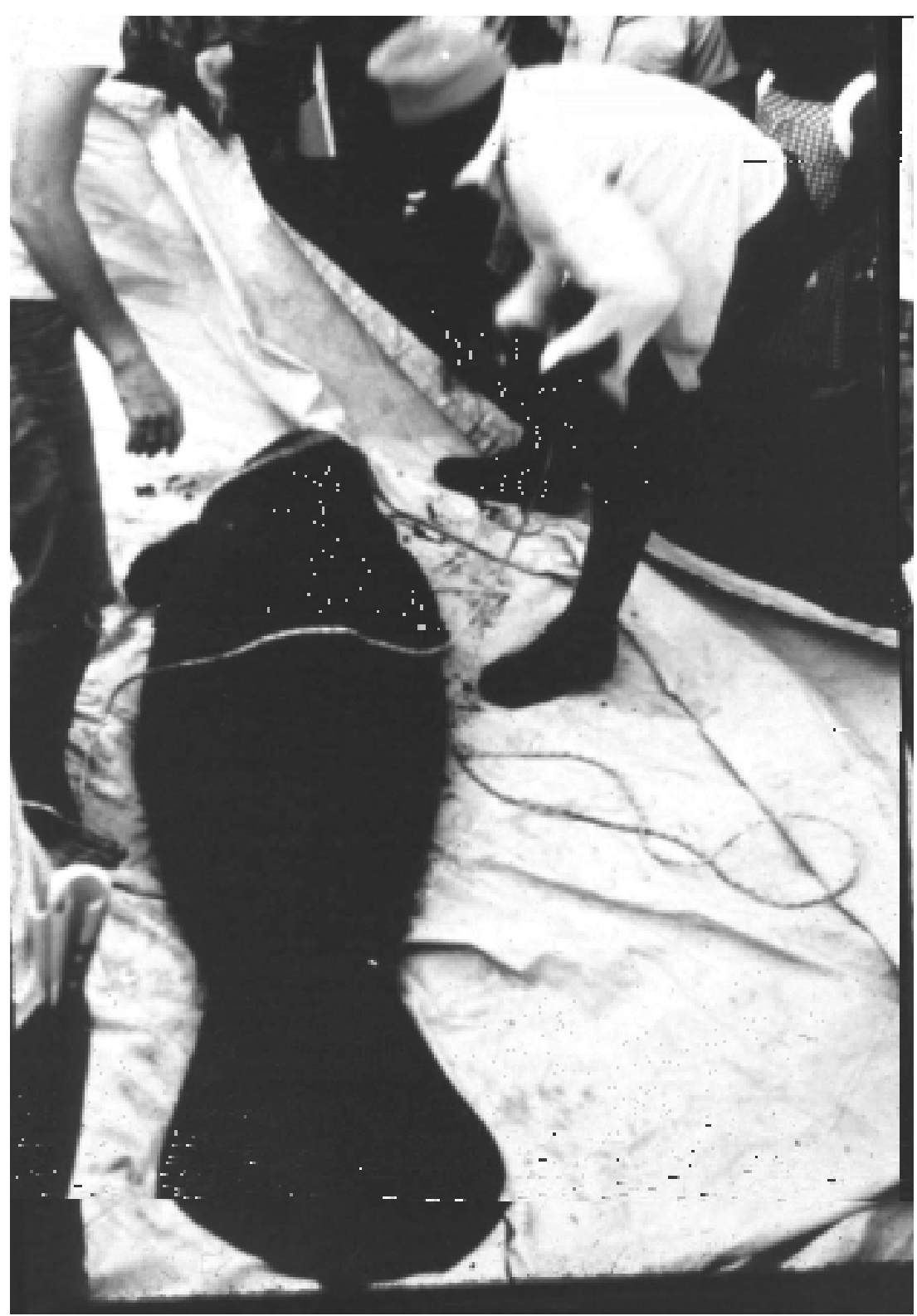

Figure 2. Historical photo of the capture of one of the manatees impounded in the Alligator Hole River, Jamaica in 1981.

allowed us, upon examination, to confirm the gender of this animal as a female. Estimated size upon capture of the animal served to estimate its relative age. At $160 \mathrm{~cm}$ length at capture, "Dorothy" was a dependent calf of about nine months of age (using the calf length-age formula described in White and Francis-Floyd [1990]). "Dorothy" is now an adult of about 21 years of age.

A second manatee was captured in Long Bay prior to early June 1982 and brought to the river for exhibit. This animal was never restrained by tether and was reported to be much larger in length and girth than the first animal upon arrival. The manatee, nicknamed "Pearl" by Hurst (1987), was reported to be pregnant and to have given birth in the river based on its subsequent thinner shape after being impounded (K.Jones, pers. comm.).
This animal was recognized as the largest of all manatees in the river, but noticeably slender in shape (P.Rochester, pers. comm.). If we assume that "Pearl" arrived at the Alligator Hole River as a reproductively active female. Its age at impoundment must have been at least 3 to 4 years, as this appears to be the age of sexual maturity for female manatees (Marmontel, 1995; Rathbun et al., 1995). Our team never sighted this manatee during our research period, and one of the wardens recalled not seeing this animal since April 1991 (P.Rochester, pers. comm.). Her status is thus uncertain, but she most probably has since then died.

A third manatee was captured in Long Bay and purchased by a private individual for exhibit at the river. The animal was later confiscated by NRCA and tied with a rope to a 


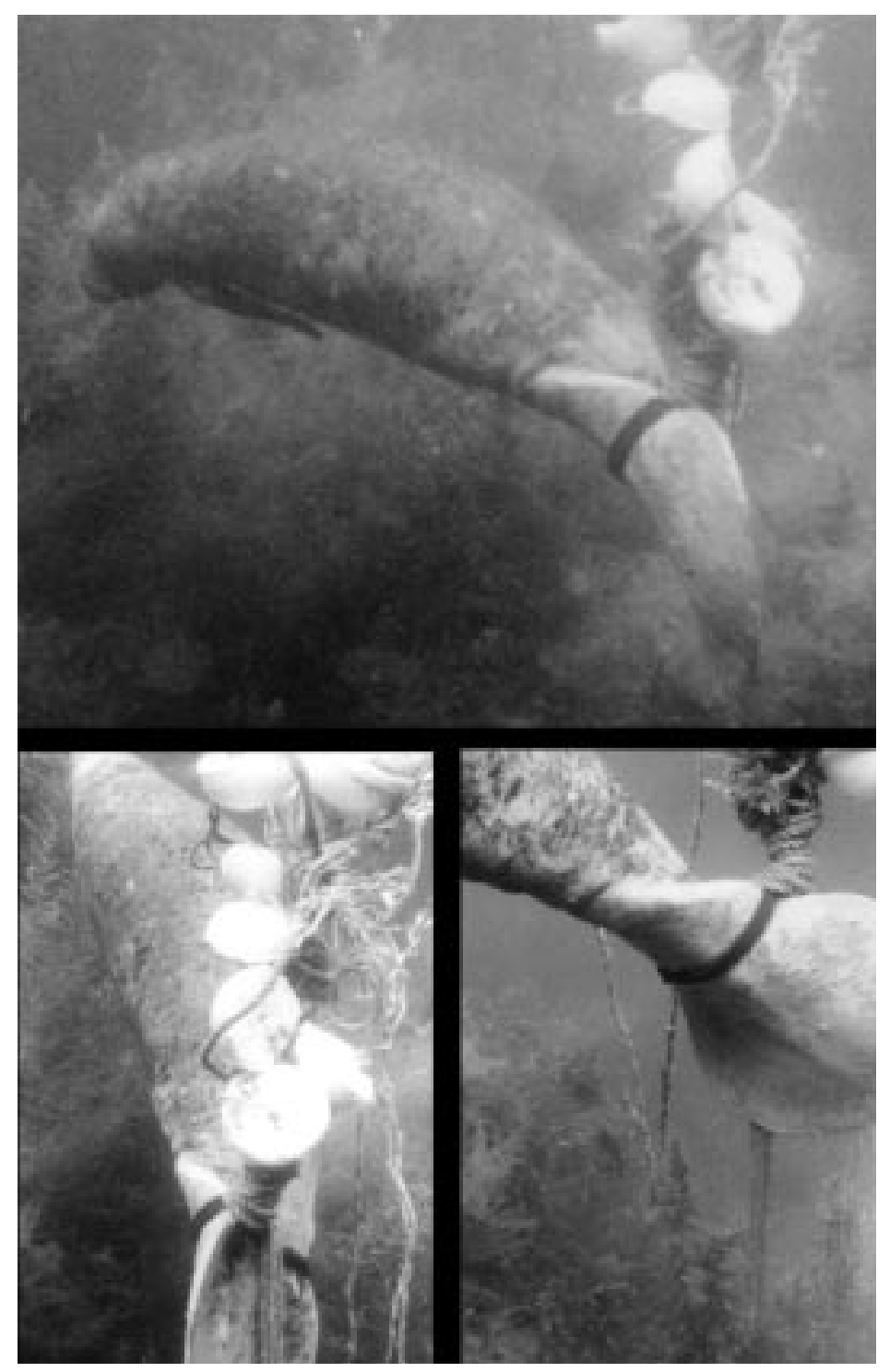

Figure 3. One of the manatees impounded in the Alligator Hole River, Jamaica in the early 1980s with a cotton rope and bicycle rubber tube tethered to its caudal peduncle to restrict its movements for exhibition.

submerged anchor. The animal was kept in the upper portions of the river to attract the first two manatees to that area for impoundment. Hurst (1987) reported that this animal was a female of about 180 to $210 \mathrm{~cm}$ in length and that it was visited by the other two manatees during the night. Hurst (1987) nicknamed this manatee "Hughette" and planned attaching a radio-collar to follow its movement patterns and food habits as part of his studies at Alligator Hole River. However, on 28 August 1983 a vandal cut the rope restraining the animal, giving the animal access to the entire river.

We sighted this animal on three occasions on 22 and 24 June 1991, and recognized it by undulated left-sided tailstock and fluke. L. Hurst's personal observation of this animal in 1983 assured that his gender determination (female) was accurate. "Hughette" probably arrived in Alligator Hole River as a weaned calf of 1.5 to 2 years of age, now an adult of about 21 to 22 years of age.

A fisherman caught a fourth manatee in a beach seine days before 17 April 1985, 0.9km west of Alligator Hole River. The animal was confiscated by NRCA and towed to Parquhar's Beach for transport to the river. The fisherman who captured the animal requested payment of $\mathrm{J} \$ 1,000$ as compensation for his time. On 17 April 1985 , the manatee, of about $152 \mathrm{~cm}$ in length, was tied by the tail in the upper portion of the river for exhibit. Hurst (1987) nicknamed this animal "Joan" and reported it as a female. 
We observed this animal three times on 20 June 1991. It was identified by a deep, mostly healed cut on the right side of his tail-stock, with a rope and net attached to the left side of the tail-stock and fluke. "Joan" was observed not to use its fluke for swimming, but rather its front flippers. After our original report of this animal's status to the NRCA, efforts were made to capture the animal and free it from the rope attached to its tail. In October 1992, T.Carr (pers. comm.) and Sea World of Florida veterinarian T.Campbell captured "Joan", confirmed it was a female and detached the rope and net. After an examination by the veterinarian, the $418 \mathrm{~kg}$ animal was released back in the river. "Joan" was originally captured still a dependant calf of about seven months of age. "Joan" by now is an adult of about 17 years of age.

\section{Discussion}

Our study suggests that at least three manatees currently reside in the Alligator Hole River. The fourth animal ("Pearl") appeared to have died in the spring of 1991. Two of the animals appeared externally healthy (i.e. no sign of emaciation, no obvious injuries or traumas). One manatee ("Joan") was observed moving extremely slow, using only its front flippers for locomotion due to a severe cut in the right side of the peduncle. This cut was produced by the rope and net surrounding its tail when the animal was tied to shore. Nevertheless, upon examination on October 1992, the female seemed to feed well as its body conformation appeared normal.

Not surprisingly, all animals in this study were extremely evasive of humans, and understandingly so. The three animals observed were not only captured and moved to a new environment, but cruelly tied to shore for long periods of time, in some cases over a year. This procedure caused wounds and marks in the three animals observed. When approached, all animals fled and hid underneath the undercut, in most cases in the west side ledge. The preponderance of the information available to us, together with our examinations suggests that all of the animals present in the river are females.

\section{Management and Conservation Implications}

Manatees are protected by law in Jamaica (Shaul and Haynes, 1986), and while law enforcement is inadequate (Lefebvre et al., 2001), the responsibility of managing and preserving the species lies within Jamaica's NRCA. Given Jamaican manatee's low population numbers, and the observed degradation of the Alligator Hole River possibly due to the same manatees impounded there (as evidence by less concentrations of morass weed and less visibility in the lower and middle river due to suspended silt matter in the water column), no justification exists, not even for education, to hold three reproducing female manatees (actually $10-21 \%$ of the total Jamaican population) apart of the rest of the Jamaican manatee gene pool. In endangered species management, reproducing females are highly valued and represent a crucial component of the population. The only justification for a semi-captive population of Jamaican manatees would be to aid their propagation by a well established, funded and properly run breeding and release program. This was one of the intents of Operation Sea Cow from its conception (Hurst, 1987, Lefebvre et al., 2001), but as the operation developed, the project went stray on responsibly taking care and managing the manatees held at the Alligator Hole River. It is not clear whether the river can sustain indefinitely the small manatee population impounded there, not to say any more manatees. There is an urgent need to closely monitor the manatees at the Alligator Hole River, as well as the river itself. Since 1996, an intermittent monitoring program was established by the NRCA, and given the depletion of food resource by the animal, a program for supplemental feeding was established. Dynamiting and spearfishing in the river must be prohibited and this measure strongly enforced. Introduction of any other manatees or wildlife (i.e. crocodiles) is not recommended until a thorough study is prepared.

Until a comprehensive conservation plan and breeding/ release research program for manatees in Jamaica is developed and funded, we strongly recommend the preparation and development of a release and tracking project for the manatees now impounded in the river, using satellite radio-transmitters, which would allow monitoring their re-adaptation to the wild. Such program has been under consideration by the NRCA together with local and international non-government organizations, but to date (June 2003), none of the animals have been released. The recommendations slated above will ultimately serve to aid the survival of the manatees not only in the Alligator Hole River and Jamaica, but throughout the Caribbean.

\section{Acknowledgements}

We thank the following persons for their help during our stay in Jamaica: Y.Strong, D.Jackson, A.Donaldson, K.Jones, M.Smith, P.Rochester, P.Morgan, and J.Marley. Without the help of local fishermen, our work at the Alligator Hole River would not have proceeded as smoothly as it went; they also provided for a most rewarding cultural exchange. L.Hurst, T.Carr, P.Thompson and R.K.Bonde provided valuable information regarding the study site and the manatees. M.Torres-Carambot (UMET/NSF MIE Scholar) kindly assisted in the preparation of the manuscript, and we acknowledge two anonymous reviewers for their comments and suggestions.

\section{References}

Fairbairn, P.W. and Haynes, A.M. (1982) Jamaican surveys of the West Indian manatee (Trichechus manatus), dolphin (Tursiops truncatus), sea turtles (Families Cheloniidae and Dermachelydae) and booby terns (Family Laridae). FAO Fishery Report 278: 289-295.

Goose, P.H. and Hill, R. (1851) A Naturalist Sojourn in Jamaica. Longman, Brown, Green and Longmans, London. 
Hurst, L. (1987) The status and distribution of the Wets Indian manatee (Trichechus manatus) in Jamaica, with an evaluation of the aquatic vegetation of Alligator Hole River [thesis]. University of Florida, Gainesville, Florida.

Lefebvre, L.W., O'Shea, T.J., Rathbun, G.B. and Best, R.C. (1989) Distribution, status, and biogeography of the West Indian manatee. Pages 567-610 in Woods, C.A. (Ed.) Biogeography of the West Indies. Sandill Crane Press, Gainesville, Florida.

Lefebvre, L.W., Marmontel, M., Reid, J.P, Rathbun, G.B. and Domning, D.P. (2001) Status and biogeography of the West Indian manatee. Pages 425-474 in Woods, C.A. and Sergile, F.E. (Eds) Biogeography of the West Indies, 2nd ed. CRC Press, Boca Ratón, Florida.

Lewis, C.B. (1949) Mermaids and manatees. In Glimpses of Jamaican Natural History, Vol. 1. Institute of Jamaica, Kingston, Jamaica.

Marmontel, M. (1995) Age and reproduction in female Florida manatees. Pages 98-119 in O'Shea, T.J., Ackerman, B.B. and Percival, H.F. (Eds) Population Biology of the Florida Manatee (Trichechus manatus latirostris). National Biological Service, Information and Technology Report 1.

Marsh, H. and Lefebvre, L.W. (1994) Sirenian status and conservation efforts. Aquatic Mammals 20: 155-170.
[NRCA] Natural Resources Conservation Authority (1993) Management Plan for the West Indian Manatee in Jamaica. Natural Resources Conservation Authority, Kingston, Jamaica.

Neish, W.D. (1896) The manatee (Manatus australis). Journal of the Institute of Jamaica 2: 287-288.

Powell, J.A. (1978) Evidence of carnivory in manatees (Trichechus manatus). Journal of Mammology 59: 442.

Rathbun, G.B., Reid, J.P., Bonde, R.K. and Powell, J.A. (1995) Reproduction in free-ranging Florida manatees. Pages 135156 in O'Shea, T.J., Ackerman, B.B. and Percival, H.F. (Eds) Population Biology of the Florida Manatee (Trichechus manatus latirostris). National Biological Service, Information and Technology Report 1.

Shaul, W. and Haynes, A. (1986) Manatees under struggle for survival. Jamaica Journal 19: 29-36.

Strong, I., Mignucci-Giannoni, A.A., Donaldson, A., Mckoy, D. and Miller, D. (1991) Report on the West Indian Manatee Project. Natural Resources Conservation Authority, Kingston, Jamaica.

White, J.R. and Francis-Floyd, R. (1990) Manatee biology and medicine. Pages 601-623 in L. Dierauf (Ed.) CRC Handbook of Marine Mammal Medicine: Health, Diseases and Rehabilitation. CRC Press, Boca Ratón, Florida.

Woodley, J. D. (1968) A history of the Jamaican fauna. Jamaica Journal 2(3): 14-20. 